\title{
Transshipment model considering environmental cost using mixed integer linear programming: Beef distribution problem
}

\author{
Januardi Januardi ${ }^{1, *}$, Zakia Puspa Ramdhani ${ }^{1}$ and Rizky Novera \\ Harnaningrum ${ }^{1}$ \\ 1 Department of Industrial Engineering, Institut Teknologi Sepuluh Nopember \\ East Java, Surabaya, Indonesia \\ E-mail: 〈\{januardi.17024,novera.17024\}@mhs.its.ac.id〉,〈zakiapuspa24@gmail.com〉
}

\begin{abstract}
The operational research paper in the transportation model nowadays is heading to the environmental issue. One of the famous operational research models is transshipment. Transshipment is an expanded model of transportation, in each distribution center between the start to the destination point. In this research, the transshipment model is integrated into an environmental function. The challenge is to find the right shipment of each route from the start, distribution, and destination point considering the transportation cost and carbon emission. This research proposed a transshipment model by minimizing transportation and carbon emission cost using mixed-integer linear programming for model formulation. The solution searching used branch and bound method. This research analyzed the environmental objective function and constrain effect in the transshipment model. The model was tested in a beef distribution case study in Bogor, Indonesia that has eight source points, three distribution centers, and six destination points. The model was experimented using carbon emission limitation scenarios. The optimum result in source allocation, distribution and destination were different between the two scenarios. The carbon emission limitation affected carbon emission production and total cost.
\end{abstract}

Keywords: branch and bound, environmental cost, green transshipment, mixed integer linear programming

Received: August 11, 2019; accepted: July 15, 2020; available online: December 18, 2020

DOI: $10.17535 /$ crorr.2020.0013

\section{Introduction}

Nowadays transportation is one of the fundamental needs in society. It is dominantly consumes a large amount of oil-based energy. This contributes to carbon emission production in the air. To help solving the problem, many researchers try to connect the environmental issue to operation research in the objective function or constraint [11]. Transshipment problem is an expansion problem of transportation where goods shipped from the source point is sent to the destination via the distribution center (transshipment nodes) [2]. Distribution center acts as a distribution agent in supply chain and warehouse in industry. Because the supply chain is one of the fundamental factors in the business process of the industry, the transshipment problem is important. In many research and application, transshipment is optimized to find the lowest total cost. However, transshipment research with environmental issue is rare. From those problems, this research challenge is to make the right decision in transshipment problem by route allocation by minimizing transportation cost and environmental impact. There are many factors considered in business process that may gain more carbon productions. Company

${ }^{*}$ Corresponding author. 
decision on price start the carbon production through demand generation [8].The effort to fulfill the demand also generates more carbon emission through shipment and distribution process.

To accept the challenge, this research used mixed-integer linear programming for model formulation. The model is in deterministic settings. The environmental issue is in objective function and constraint. There is only a single objective, i.e. to minimize the total cost. The total cost is the addition of transportation and carbon emission cost. The model was tested in the beef distribution in Bogor, Indonesia. Bogor city is surrounded by many livestock so the meat demand is always fulfilled. However, the current challenge is not just to fulfill the demand by minimizing cost, but also by minimizing environmental impact. The demand data of beef meat is obtained from beef consumption [6] and the total population [5]. The production of beef data was obtained from [4].

\section{Literature review}

\subsection{Green transshipment in operational research}

One of the challenging problems in green transportation is to determine the optimum route of distribution process by reducing carbon emission. Green transportation is a distribution service to decrease the negative impact of human health and a sustainable ecosystem. The problems of green transportation include the shortest route and scheduling determination. This knowledge will continue to grow as smart transportation is developed [11]. Transshipment study is one of the operational research problems that assumed all source and distribution point is shipping at the same time. Transshipment has greater coverage than the transportation problem. It is known that transportation problems only begin from source point to the destination point. However in the transshipment problems, between those points, the route distribution need to pass through some transshipment nodes (Figure 1). The transshipment nodes in the real business application is usually called the distribution center, as a connecting nodes between source point and the destination point to make an easier traceability. In addition, this model has more routes, nodes, and variables [11].

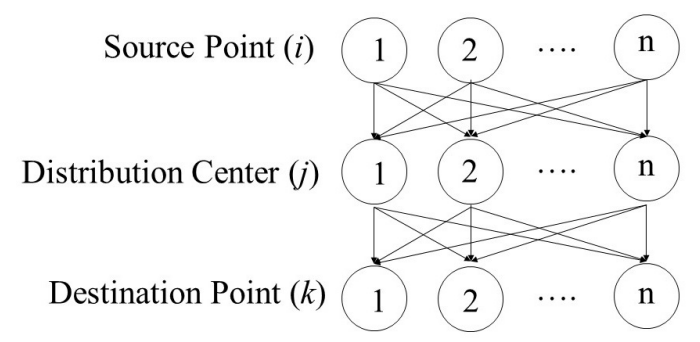

Figure 1: Graphic nodes of transshipment problem

\subsection{Beef distribution in Bogor, West Java, Indonesia}

Beef distribution in Bogor, Indonesia is started with live cattle transportation from local cattleman around Bogor Regency [10]. Then, the cattle are sent to feedlots to fill them with nutrition. After the cattle are filled up, they are sent to slaughterhouse to be transformed into beef meat. Before being purchased by the customer, the beef is distributed to all local market in Bogor City. According to [10] the supply chain design of beef in Bogor can be seen on Fiqure 2 . 


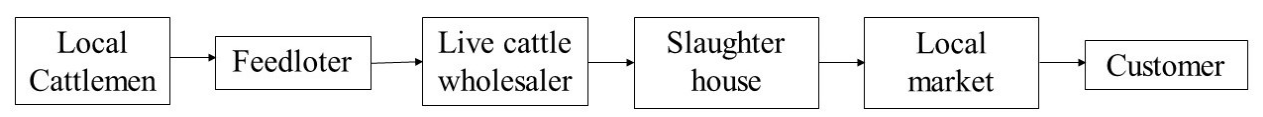

Figure 2: Beef supply chain in Bogor City

Model efficiency of the beef supply chain is only from local cattlemen, slaughterhouse, then to customer [13]. In the transshipment model, the slaughterhouse acts as a distribution center with no stocking process. However, Bogor customers usually purchase beef from the local market. In this model, the destination point is the local market (Figure 3).

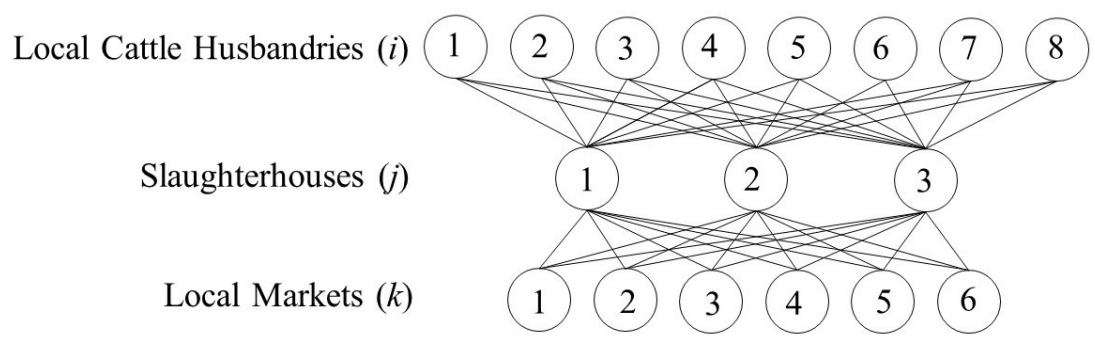

Figure 3: Graphic nodes of beef distribution in Bogor, Indonesia

\subsection{Research gap}

Green transshipment research considering environmental cost is done in this paper. To know the gap of this research, different researches about transportation have been done before. The list of the research gap is given in Table 1.

\begin{tabular}{|c|c|c|c|c|}
\hline Author(s) & Model & Method & Functional area & Research problem \\
\hline$[3]$ & $\begin{array}{l}\text { Supply chain } \\
\text { configuration }\end{array}$ & $\begin{array}{l}\text { Spanning tree- } \\
\text { particle Swarm } \\
\text { optimization }\end{array}$ & $\begin{array}{l}\text { Green } \\
\text { transportation }\end{array}$ & $\begin{array}{l}\text { Customer transportation } \\
\text { considering green supply } \\
\text { chain }\end{array}$ \\
\hline$[14]$ & $\begin{array}{l}\text { Mixed integer } \\
\text { linear program }\end{array}$ & $\begin{array}{l}\text { Epsilon constraints } \\
\text { technique }\end{array}$ & $\begin{array}{l}\text { Green } \\
\text { transportation }\end{array}$ & $\begin{array}{l}\text { Green routing considering } \\
\text { environmental and } \\
\text { financial costs }\end{array}$ \\
\hline$[9]$ & $\begin{array}{l}\text { Mixed integer } \\
\text { linear program }\end{array}$ & $\begin{array}{l}\text { Nearest neighbor } \\
\text { algorithm }\end{array}$ & Transshipment & $\begin{array}{l}\text { Container intermodal } \\
\text { transshipment }\end{array}$ \\
\hline$[12]$ & $\begin{array}{l}\text { Linear } \\
\text { program }\end{array}$ & E-constraint & $\begin{array}{l}\text { International } \\
\text { meat supply chain }\end{array}$ & $\begin{array}{l}\text { Food distribution } \\
\text { network model }\end{array}$ \\
\hline$[15]$ & $\begin{array}{l}\text { Continuous } \\
\text { approximation }\end{array}$ & $\begin{array}{l}\text { Game theory, non- } \\
\text { linear optimization }\end{array}$ & $\begin{array}{l}\text { Sea } \\
\text { transportation }\end{array}$ & $\begin{array}{l}\text { Seaport-dry network design } \\
\text { considering multimodal } \\
\text { transportation and carbon } \\
\text { emission }\end{array}$ \\
\hline $\begin{array}{l}\text { This } \\
\text { article }\end{array}$ & $\begin{array}{l}\text { Mixed integer } \\
\text { linear program }\end{array}$ & Branch and bound & $\begin{array}{l}\text { Green } \\
\text { transshipment }\end{array}$ & $\begin{array}{l}\text { Transshipment by } \\
\text { minimizing transportation } \\
\text { and environmental costs }\end{array}$ \\
\hline
\end{tabular}

Table 1: Research gap 
Table 1 shows that some transportation and transshipment researches applied mixed-integer linear programming (MILP), because discrete and continuous decision is needed. Discrete decision is used for route selection and continuous decision is used for the number of shipment product through certain routes. MILP is linear programming where some of the solution elements are in integer. This program can be used as continuous or discrete parameter. The algorithms used to solve this problem are branch and bound, cutting-plane, Gomory's cuts, etc. $[1]$.

\section{Proposed model}

The mathematical model is formulated to find the lowest transportation and carbon emission cost. The model has some assumption and limitation such as the model is in deterministic settings, the velocity of vehicle is constant, there are no road obstacle (road physical condition, traffic, etc.), the trip is done only from source to destination point, the money currency is in Indonesian rupiah ( $\mathrm{Rp}$ ), and the analyzed environmental impact is carbon monoxide (CO) production. The model is solved by Lingo v.11 software. The notations and model formulation are given below.

\section{Notations}

Indexes:

$i=$ source point $(i=1,2,3, \ldots, I)$

$j=$ distribution center $(j=1,2,3, \ldots, J)$

$k=$ destination point $(\mathrm{k}=1,2,3, \ldots, K)$

Decision variables:

$X_{i j}=$ product quantity that is shipped from source point $i$ to distribution center $j$ (unit) $Y_{j k}=$ binary variable $(1$ if the shipment is allocated from the distribution center $j$ to destination point $k, 0$ otherwise)

Parameters:

$C T_{i j}=$ transportation cost from source point $i$ to distribution center $j$

(Rp/unit)

$C T_{j k}=$ transportation cost from distribution center $j$ to destination point $j$

$C E_{i j}=$ carbon emission cost from source point $i$ to distribution center $j$

$C E_{j k}=$ carbon emission cost from distribution center $j$ to destination point $k(\mathrm{Rp} / \mathrm{gCO})$

$P_{i}=$ maximum quantity of production in source point $i$

$D_{k}=$ minimum quantity of demand in destination point $k$

$C a p_{j}=$ holding capacity in distribution center $j$

$C O_{i j}=$ carbon emission production from source point $i$ to distribution center $j$ (gCO/unit)

$C O_{j k}=$ carbon emission production from distribution center $j$ to destination $k$ (gCO/unit)

$C E S_{i j}=$ carbon cap from source point $i$ to distribution center $j$

$C E S_{j k}=$ carbon cap from distribution center $j$ to destination point $k$

Model formulation

$$
\operatorname{Min} \sum_{i=1}^{I} \sum_{j=1}^{J}(C T i j+C E i j) X i j+\sum_{j=1}^{J} \sum_{k=1}^{K}(C T j k+C E j k) Y j k
$$

s.t.

$$
\sum_{j=1}^{J} X i j \leq P i \quad \forall i
$$




$$
\begin{gathered}
\sum_{i=1}^{I} X i j=\sum_{k=1}^{K} D j k Y j k \quad \forall j \\
\sum_{k=1}^{K} D j k Y j k \leq C a p j \quad \forall j \\
\sum_{k=1}^{K} Y j k=1 \quad \forall j \\
C O i j X i j \leq C E S i j \quad \forall i \forall j \\
C O j k X j k \leq C E S j k \quad \forall j \forall k \\
X i j \geq 0 \quad \forall i \forall j \\
Y j k \in(0,1) \quad \forall j \forall k
\end{gathered}
$$

Equation (1) in the proposed model shows the model objective function to minimize the shipment and the environmental cost. The production capacity for limiting the production in each source point (local cattle husbandry) is shown in equation (2). For limiting the unit shipment through the transshipment nodes, equation (3) is proposed to imitate the real world situation where some distribution center (Slaughterhouse) cannot accept a large number of shipments. The demand fulfillment function is introduced in equation (4). Each destination only can be fulfilled by one slaughterhouse or the distribution center, so it is represented in equation (5). The carbon limitation from source point to destination point is in equations (6) and $(7)$.

\section{Results and discussion}

\subsection{Observed system parameters}

The system parameter was obtained from beef distribution case study in Bogor, Indonesia. The system parameters of the objective function in transportation cost are presented in Table 2.

\begin{tabular}{|c|rrr|}
\hline Source point $i$ & \multicolumn{3}{|c|}{ Distribution center $j$} \\
\hline \hline & \multicolumn{1}{|c}{1} & \multicolumn{1}{|c|}{2} & 3 \\
1 & 27.62 & 11.88 & 46.18 \\
2 & 25.23 & 9.56 & 43.86 \\
3 & 35.85 & 49.90 & 14.06 \\
4 & 22.21 & 36.34 & 6.33 \\
5 & 7.66 & 18.63 & 21.16 \\
6 & 4.78 & 20.10 & 17.29 \\
7 & 11.53 & 10.61 & 35.35 \\
8 & 44.70 & 33.46 & 52.15 \\
\hline
\end{tabular}

Table 2: Transportation cost from source point $i$ to distribution center $j$ ( $R p /$ unit) 


\begin{tabular}{|c|c|c|c|}
\hline Destination point $k$ & \multicolumn{3}{|c|}{ Distribution center $j$} \\
\hline & 1 & 2 & 3 \\
\hline 1 & 181021.67 & 95113.08 & 465338.18 \\
\hline 2 & 1627577.94 & 408625.95 & 3365969.70 \\
\hline 3 & 188180.72 & 64431.44 & 487838.05 \\
\hline 4 & 185112.55 & 60340.56 & 484769.89 \\
\hline 5 & 675350.69 & 353024.22 & 1442794.65 \\
\hline 6 & 1170483.20 & 512086.40 & 2833101.38 \\
\hline
\end{tabular}

Table 3: Transportation cost from distribution center $j$ to destination point $k$ ( $R p$ )

Table 2 shows the unit cost of shipping material or product from source point (local cattle husbandry) to distribution center (Slaughterhouse). There is no holding or inventory activity in the distribution center, since there is only meat processing to be distributed to the destination point or local markets. Table 3 shows the cost of shipping material from distribution center to the destination point. To know the production capacity in each point and the demand unit of each destination point, it is shown in Tables 4-5.

\begin{tabular}{|c|c|}
\hline Source point $i$ & Maximum production (unit) \\
\hline \hline 1 & 169745 \\
2 & 178846 \\
3 & 162236 \\
4 & 183397 \\
5 & 198187 \\
6 & 276006 \\
7 & 187265 \\
8 & 174523 \\
\hline
\end{tabular}

Table 4: The production capacity of source point $i$

\begin{tabular}{|c|c|}
\hline Destination point $k$ & Minimum demand (unit) \\
\hline \hline 1 & 14550.80 \\
2 & 98537.93 \\
3 & 14550.80 \\
4 & 14550.80 \\
5 & 43675.33 \\
6 & 94619.80 \\
\hline
\end{tabular}

Table 5: The demand from destination point $k$

As a supported data for environmental constraint, the research used The Regulation of Environmental Ministry of Indonesia (Peraturan Menteri Negara Lingkungan Hidup Nomor 12 Tahun 2010). The model assumes that the vehicle carbon production is stable. There is only an increase for route range, instead of the machine performance. The data for Table 3 is used to estimate the total environmental cost which is multiplied by Rp. 2.94 /g CO as the environment cost to produce Carbon Monoxide. The data are shown in Tables 6-7. 


\begin{tabular}{|c|ccc|}
\hline Source point $i$ & \multicolumn{3}{|c|}{ Distribution center $j$} \\
\hline \hline & 1 & 2 & 3 \\
1 & 1.25 & 0.54 & 2.09 \\
2 & 1.14 & 0.43 & 1.98 \\
3 & 1.62 & 2.26 & 0.64 \\
4 & 1.00 & 1.64 & 0.29 \\
5 & 0.35 & 0.84 & 0.96 \\
6 & 0.22 & 0.91 & 0.78 \\
7 & 0.52 & 0.48 & 1.60 \\
8 & 2.02 & 1.51 & 2.36 \\
\hline
\end{tabular}

Table 6: Carbon emission production from source point $i$ to distribution center $j$ ( $g C O$ )

\begin{tabular}{|c|rrrr|}
\hline Destination point $k$ & \multicolumn{3}{|c|}{ Distribution center $j$} \\
\hline \hline & \multicolumn{1}{|c}{1} & 2 & \multicolumn{1}{c|}{3} \\
1 & 8190.06 & 4303.25 & 21053.55 \\
2 & 73637.40 & 18487.69 & 152288.41 \\
3 & 8513.96 & 2915.11 & 22071.52 \\
4 & 8375.15 & 2730.02 & 21932.71 \\
5 & 30555.26 & 15972.07 & 65277.15 \\
6 & 52956.81 & 23168.60 & 128179.55 \\
\hline
\end{tabular}

Table 7: Carbon emission production from distribution center $j$ to destination point $k$ ( $g C O$ )

\subsection{Numerical experiments}

This research involved transportation and carbon emission cost. The model scenario is only in with or without carbon limitation from local cattle as source point, slaughterhouse as a distribution center, and local market as the destination point. To apply the without carbon limitation scenario, equations (6)-(7) were not included in the optimization phase. Without those equations, there are some differences in route selection, carbon production estimation, and total cost estimation. The route allocation without carbon cap constraint is presented in Figure 4.

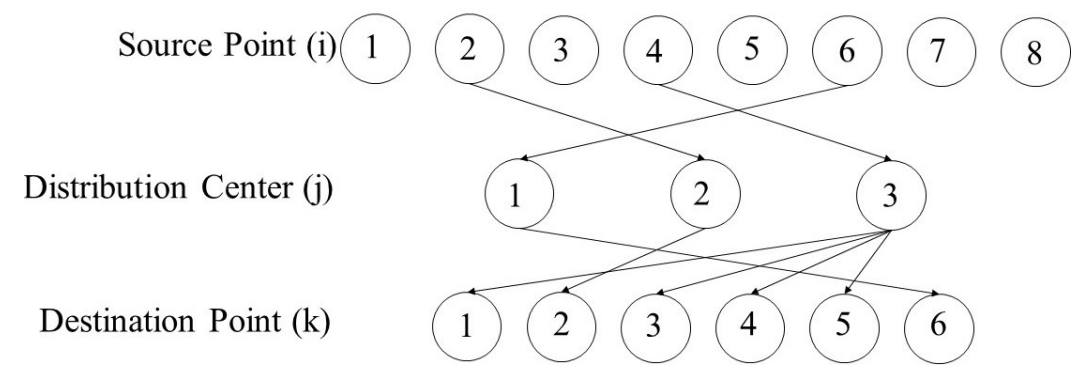

Figure 4: Route allocation in transhipment without carbon limit constraint

The optimum solution without carbon limit constraint shows that all distribution center got the shipment from all source point. It is different from the scenario with carbon cap constraint. The constraint forced the model to allocate all the remaining resources to another distribution center. In without carbon limitation, the total cost is lower than with carbon limit constraint 
but has a large amount of carbon emission productions. The optimum solution of without carbon cap scenario is finding the shortest route. However, the carbon cap scenario applies carbon emission production limitation so not all route can be passed for the product shipment. Therefore, the carbon emission of each route is small. The lowest carbon limitation from the source point to a distribution center is $16.000 \mathrm{~g}$ of $\mathrm{CO}$, from distribution center to destination point is $130.000 \mathrm{~g}$ of CO. The differences in cost and carbon emission in with or without carbon limit constrain are shown in Table 8.

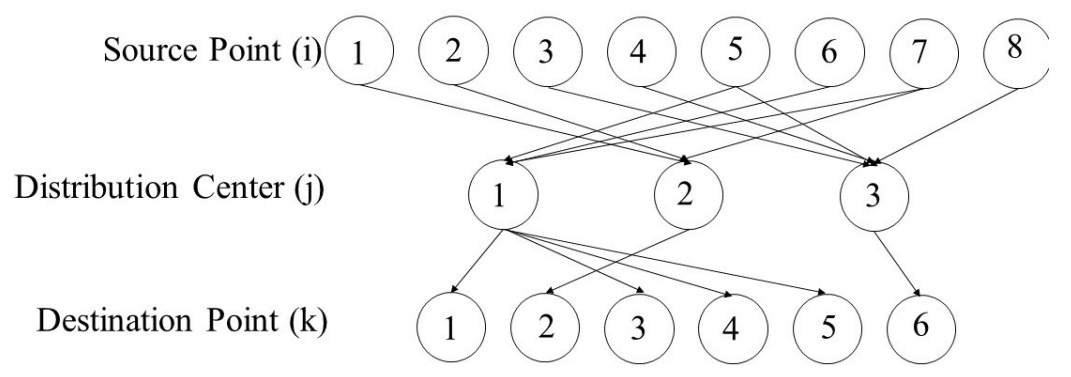

Figure 5: Route allocation in transshipment with carbon limit constraint

\begin{tabular}{|l|cc|}
\hline Criteria & Without carbon constraint & With carbon constraint \\
\hline \hline Transportation Cost & Rp 5.554.297,71 & Rp 6.126.143,02 \\
Carbon Emission Cost & Rp 852.116,32 & Rp 939.846,35 \\
Total Cost & Rp 6.406.414,02 & Rp 7.065.989,37 \\
Carbon Emission Production (CO) & $415.230,80$ gram & $369.852,1$ gram \\
\hline
\end{tabular}

Table 8: Differences of transshipment model without and with carbon limit constraint

\subsection{Sensitivity analysis}

The given carbon limit is added 10.000 gram to 30.000 gram of CO to do the sensitivity analysis. The result in total cost is shown in Figure 6. If the carbon limitation is added, then the cost will be decreased, however, the carbon emission production is increased. The lowest carbon limitation makes the distribution allocation is equal. The lowest cost is gained when there is no limit in carbon emission limitation. The increase of carbon emission production in carbon limit addition is in Figure 7.

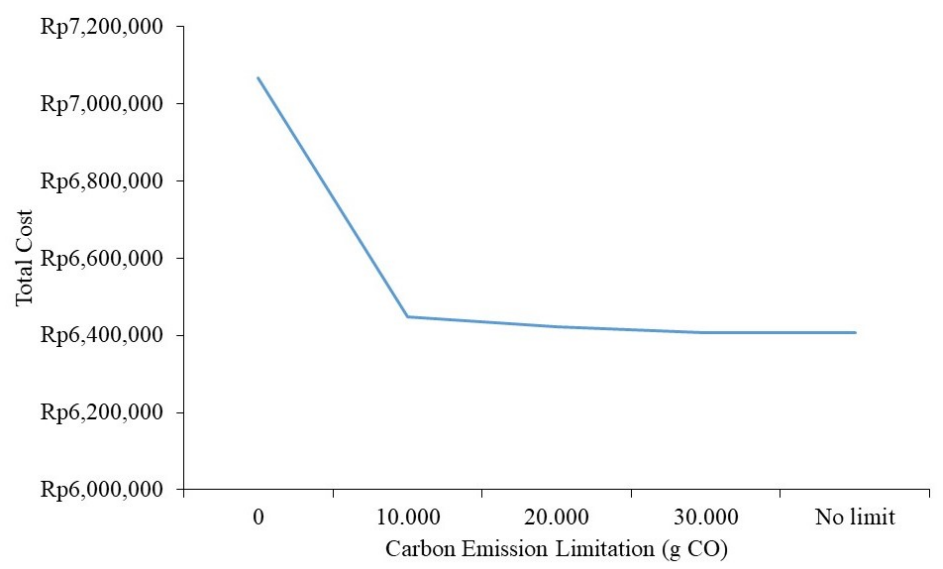

Figure 6: Sensitivity analysis of total cost with carbon emission limitation 


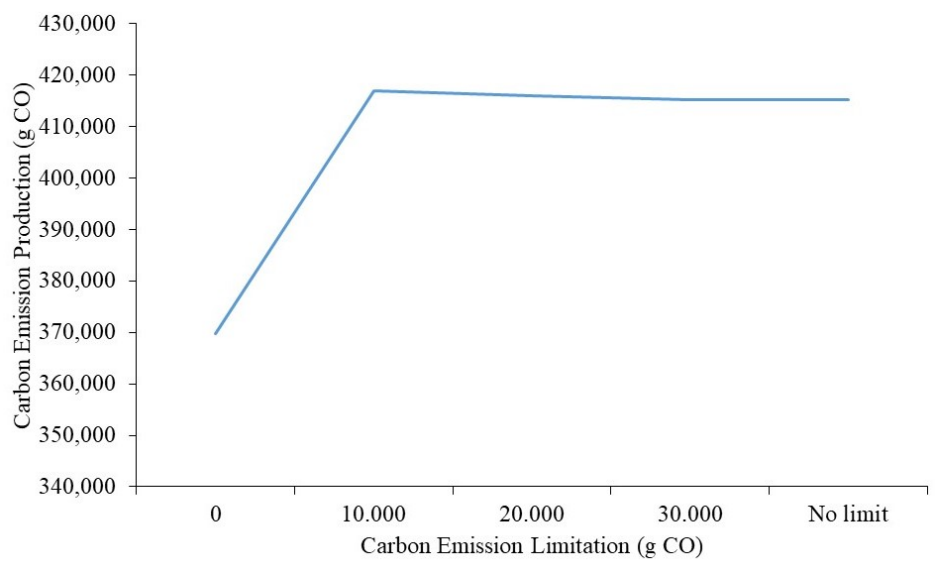

Figure 7: Sensitivity analysis of carbon emission production with carbon emission limitation

\section{Conclusion}

Mixed-integer linear programming is developed in green transshipment problem by considering transportation and environmental cost in the form of carbon emission cost. Then, carbon emission limitation in constraint in each route is applied. The calculation result is transshipment model without carbon limit that has a lower total cost than carbon limit applied; however, the carbon emission production is higher. Furthermore, of carbon limitation model, the addition of the limitation makes the total cost decrease and carbon emission increase. The model's novelty is by applying carbon emission minimization in objective function and carbon emission limitation in constraint due to minimize the total cost of shipment and carbon production.

The model in this research has some limitations and assumptions. The model settings are in deterministic. Applying uncertainty factors in the transshipment model can make the research more interesting. In addition, to apply the model in the real-world situation, the machine performance and maintenance of shipment vehicles should be included.

\section{References}

[1] Abaffy, J. and Fodor, S. (2013). Solving integer and mixed-integer linear problems with abs method. Acta Polytechnica Hungarica, 10(7), 81-98. doi: 10.12700/APH.10.07.2013.7.7

[2] Agadaga, O. G. and Akpan, N. P. (2017). Transshipment problem and its variants: A review. Mathematical Theory and Modeling, 7(2), 19-32. https://www.iiste.org/Journals/index.php/ MTM/article/view/35765

[3] Hong, Z., Dai, W., Luh, H. and Yang, C. (2018). Optimal configuration of a green product supply chain with guaranteed service time and emission constraints. European Journal of Operational Research, 226(2), 663-677. doi: 10.1016/j.ejor.2017.09.046

[4] Indonesian Bureau of Statistics. (2016). Kabupaten Bogor dalam Angka 2016. Bogor: Indonesian Bureau of Statistics.

[5] Indonesian Bureau of Statistics . (2017). Kota Bogor dalam Angka 2017. Bogor: Indonesian Bureau of Statistics.

[6] Indonesian Ministry of Agriculture. (2017). Statistik Peternakan dan Kesehatan Hewan. Jakarta: Indonesian Ministry of Agriculture.

[7] Indonesian Ministry of Environment. (2010). Peraturan Menteri Negara Lingkungan Hidup Nomor 12 Tahun 2010 tentang Pelaksanaan Pengendalian Pencemaran Udara di Daerah. Jakarta: Indonesian Ministry of Environment. 
[8] Januardi and Widodo, E. (2020). Response surface methodology of dual-channel green supplychain pricing model by considering uncertainty. Supply Chain Forum: An International Journal, 1-12. doi: 10.1080/16258312.2020.1788904

[9] Munim, Z. H. and Haralambides, H. (2018). Competition and cooperation for intermodal container transshipment: A network optimization approach. Research in Transportation Business and Management, 26(2018), 87-99. doi: 10.1016/j.rtbm.2018.03.004

[10] Rachman, N. M. (2016). Analisis Jaringan Distribusi Daging Sapi di Kota Bogor. (Undergraduate Thesis). Bogor: IPB University.

[11] Salimifard, K., Shahbandarzadeh, H., and Raeesi, R. (2012). Green transportation and the role of operation research. International Proceedings of Computer Science and Information Technology, 26, 74-79. http://ipcsit.com/vol26/15-ICTTE2012-T022.pdf

[12] Soysal, M., Ruwaard, J. M. B. and Vorst, J. G. A. J. V. D. (2013). Modeling food logistics networks with emission considerations: The case of an international beef supply chain. International Journal of Production Economics, 152, 57-70. doi: 10.1016/j.ijpe.2013.12.012

[13] Teimoury, E., Jabbarzadeh, A. and Babaei, M. (2017). Integrating strategic and tactical decisions in livestock supply chain using b-level programming, case study: Iran poultry supply chain. Plos One, 12(10), e0185743. doi: 10.1371/journal.pone.0185743

[14] Toro, E. M., Franco, J. F., Echeverri, M. G., Guimarães, F. G. and Rendon, R. A. G. (2017). Green open location-routing problem considering economic and environmental costs. International Journal of Industrial Engineering Computations, 8, 203-216. doi: 10.5267/j.ijiec.2016.10.001

[15] Tsao, Y. C. and Linh, V. T. (2018). Seaport-dry port network design considering multimodal transport and carbon emissions. Journal of Cleaner Production, 199, 481-492. doi: 10.1016/j.jclepro.2018.07.137 